\title{
Is Milosevic getting a fair trial at The Hague?
}

by Sir Ivan Lawrence QC

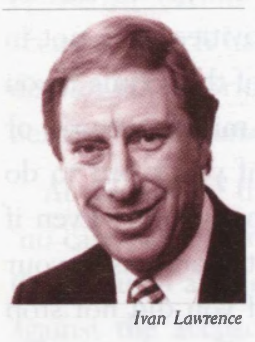

$\mathrm{T}$ the trial of Slobodan Milosevic is nowhere near completion, but already it seems that he has been tried by world opinion and the media and found guilty on all charges. So is he getting a fair trial before this International Criminal Tribunal for the former Yugoslavia at The Hague?

To most people, a trial is fair if it convicts the guilty and acquits the innocent. To the lawyer, concerned with process, a trial is fair if it conforms with such internationally accepted rules, laid down by statute or convention, as the presumption of innocence, the right for the accused to be present at his trial, to defend himself or be represented by a qualified lawyer, to have specific allegations presented clearly and simply, to have all the evidence against him disclosed with time to prepare his defence, to be tried with as little delay as possible before a properly constituted court and to have a right of appeal if he should be convicted.

Milosevic is not, of course, being tried either by world opinion or a jury, but by three judges trained and experienced in these rules and to exclude from their minds media opinion and tittle-tattle. They will concentrate their minds not on his irrelevant video display and four hour tirade about the legitimacy and results of the NATO bombing and the right of Serbs to go to war with their enemies, but on the precise accusations against Milosevic that he committed genocide, war crimes or crimes of inhumanity against innocent civilians. As to his refusal to recognise the authority of the Tribunal, that may be somewhat compromised by the fact that he committed himself to co-operating with the Tribunal, set up by the United Nations Security Council, when he signed the Dayton Accords which ended the conflict in BosniaHerzegovina.

Nevertheless, Milosevic is by no means alone in having serious doubts about the Hague Tribunal. Some doubt its political desirability. Others doubt its legitimacy. Some, who do not doubt either, have qualms about the definition of criminal culpability, which the Tribunal is developing and about the legal processes it is laying down for the achievement of justice.

\section{THE POLITICS OF THE TRIBUNAL}

Not every Government is happy about giving this institution the power to indict and try heads of state of any nation at war for the most serious of crimes for where might such power not lead? Might President Clinton be indicted for the killings that resulted from his order to bomb Somalia? Tony Blair for supporting Clinton in the Nato bombing of Belgrade without the authority of the United Nations? Might President Putin of Russia be indicted for the killings in Chechnya? Margaret Thatcher for ordering the sinking of the Belgrano in the Falklands War? Could it even be that ministers of countries who negotiated with Milosevic whilst the Balkan killings were in progress and who might be taken to have known what he was alleged to have done, be indicted on the grounds that, by dealing with him and thereby signalling encouragement, they made themselves a party to his wrongdoing?

Is there not a real danger, as Milosevic alleges, that the Tribunal will be used as a political tool of states in conflict with each other rather than as a purely legal entity for achieving universally agreed justice? Would it not, in any event, be far better for sovereign states to try their own alleged war crimes perpetrators?

Indeed is not Milosevic justifiably arguing that those who brought him before the Tribunal are inconsistent and hypocritical; for if it was considered to be so vital to have United Nations authority before the bombing started in the Gulf War why was its authority deliberately not sought before the bombing of Belgrade? And, he seems to be arguing, if the major powers did not feel that they could rely on the authority of the UN before killing innocent civilians in his country's capital city, why should he be 
expected to subject himself to that same authority to be tried for killing civilians in Yugoslavia?

Such arguments may be of little practical assistance to Milosevic now, since the Tribunal has been set up and working these past nine years and he has been brought before it with hardly any Governmental disapproval worldwide. But questions about the fairness of the process may be another matter.

\section{THE LEGITIMACY OF THE TRIBUNAL}

The creation of the Tribunal ought, ideally, to have been authorised by the full General Assembly of the UN; in fact its authority comes only from the seven countries represented in the Security Council. The explanation for this, it was said, was that the establishment of such a Tribunal to bring to justice those accused of war crimes in the former Yugoslavia and Rwanda was so urgent that there was not time to take the matter through the full procedures of the General Assembly. Others have said that the truer reason for the short cut was that the major powers did not believe that they would carry the measure with the votes of enough countries however long the process lasted.

Some ask how the Tribunal can claim to be objective when the founding statute requires it to be an institution, which both prosecutes and judges in the same cause? Where is that apparent objectivity, others argue, when Article 1 of the same statute declares that 'The International Tribunal shall have the power to prosecute persons responsible for serious violations of international humanitarian law.' not, be it noted, those allegedly responsible for such violations. Does it not seem that there is here a presumption of guilt and the need to prove innocence?

It might be suggested that Milosevic can argue such fundamental matters before the Tribunal: but that would achieve little since the Tribunal has already considered such arguments in previous cases and, unsurprisingly, found against them - and their conclusion has been upheld by the Appellate Tribunal (made up of the same level of judges in the same building) against whom there can be no further appeal.

\section{THE LAW OF CRIMINAL RESPONSIBILITY}

The laws which the Tribunal has been enforcing since its inception in 1993 might surprise, if not alarm, the British common lawyer.

Of course in order to be guilty of crimes of genocide and against humanity like murder, torture and persecution, there must be guilty conduct by the accused coupled with a guilty intent to do that wrong. But what if there is no actual evidence, direct or indirect, that an accused took part in the guilty conduct or had the necessary guilty intent?
Because of the Tribunal's doctrine of 'command responsibility' such lack of evidence is unlikely to spare him. Previous decisions of the Tribunal have established that if you are in a position of some authority, like a shift leader of a dozen guards, that may be enough for the Tribunal to infer that you knew what was going on even though there is no evidence that you actually did know: you may be found guilty if you did nothing to stop what there is no evidence you actually knew was happening. If you are party to a plan to lock up potential troublemakers in a camp and someone else commits murder or torture when you are not present and such activities were not in the original plan, you too will be guilty of that crime if you ought to have foreseen that others might torture or murder. You would certainly be guilty if you failed to do what you could to find out what was happening. Even if you had no official authority to control the actions of your subordinates you would still be guilty if you did not stop them. And you would certainly be guilty if you knew what was going on and were sickened by it but you neither ran away nor did very much to help because you had every reason to believe you would be shot by your superiors for desertion or dereliction of duty. Before this Tribunal you can even be charged and convicted twice for the same offence because your guilt may be considered to be cumulative.

Such decisions push the concept of individual responsibility for crimes to limits not previously encountered in the British courts.

\section{THE PROCEDURE}

The Tribunal's procedures will also raise many a British common-lawyer's eyebrows.

Whilst it is altogether reasonable to expect the Tribunal to address a novel situation, not specifically covered by the founding statute, by extending the law to make new rules, it is quite prepared to go further and over-ride the statute. If the statute provides for a situation which the Tribunal does not find acceptable, it has been known to argue that the statute is a treaty and therefore not set in stone and anyway, as it said in one case, there may have been a mistranslation, which no-one can have noticed hitherto, which warrants correction. In other words, the Tribunal is prepared to make up the law as it goes along - which hardly accords with normal common-law criminal law experience where it is a fundamental rule of justice that you should be able to know in advance exactly what the laws and procedures are.

Because the Tribunal judges are themselves the judges of the facts - and they do not have to leave findings of fact to a jury - they allow 'hearsay' evidence, which the United Kingdom jurisdiction excludes in case it might prejudice a jurors opinion of the accused. So what someone is overheard to be saying about the accused can form part of the evidence against him before the Tribunal, even if he 
was not present to challenge the statement, and the Tribunal will decide what weight to give that evidence, which so far, is perhaps, so good. But the Tribunal has been prepared to accept, as sufficient evidence of identification of an accused, the evidence of someone who did not know and cannot himself identify the person he saw, but who overheard a conversation several weeks after the event between people who were neither describing the event nor were present at it nor have been called to give evidence: a kind of third hand 'hearsay' identification. In the absence of identification parades, dock identification of the accused, which has such obvious dangers that it is usually disallowed in British courts, is usually accepted evidence before the Tribunal.

At the end of the prosecution's case, if a submission of 'no case to answer' is made by the defence, the test which the Tribunal applies is whether there is any evidence at all against the accused: that is not the stage of the trial to consider whether the evidence is of sufficient quality or credibility to sustain a case against the accused. Whilst that would be understandable where, as in the United Kingdom, a jury is the ultimate judge of the weight and quality of the evidence, it hardly makes sense where there is no jury and the Tribunal may have to wait several months and incur much expense and trauma to witnesses and the accused before returning the not guilty verdict they would otherwise have returned so much sooner. Since all reasonable inferences are to be drawn in favour of the Prosecution at this stage, the impression given is that the accused is expected to call evidence to prove his innocence.

Cross-examination, the common-lawyer's best instrument for exposing weakness in a witness's evidence, is restricted by this Tribunal. Counsel are expected to limit cross-examination to the subject-matter of the witnesses evidence in chief - although some lee-way is given - and attempts to shake the witness by inviting him to change his testimony are frowned upon as repetitious time-wasting. Points of law on admissibility are taken in the presence of the witness who is thereby given an opportunity to prepare himself to deal with the matter. Showing him a previous inconsistent statement may not embarrass the witness, although the inconsistency can be put to him without producing the statement - which may not have quite the same effect. Expert evidence given in another case previously before the Tribunal may be presented in transcript form, and cross-examination is therefore not available even if the evidence was not given in the presence of the current accused, the witness's credibility is in issue, and new evidence is available since the witness last gave evidence which might change the expert's conclusions: such evidence, the Tribunal has ruled, can be challenged by calling expert evidence for the defence. Once again the unfortunate impression is given that the accused has to prove his innocence. Furthermore, if the expert witness is called and one defendant is allowed to cross-examine him, the Tribunal may order that no other co-defendant can cross-examine him.

Each prosecution witness may have a further statement taken from him by counsel calling him shortly before he gives evidence, which means that he is reminded of what he is expected to say on any issue. The justification for this is presumably that if the witness has made several statements over a number of years following a traumatic event, it will lessen the chance of him having to rely on a confused recollection. The trouble with this is that the similarity between this and coaching a witness appears to be dangerously close. The fact that this same facility is allowed to the defence does not really balance the matter up, because the prosecution goes first and has to produce sufficient evidence of guilt before the defence even has to answer.

There are other variations from common-law practise. Submissions of 'no case to answer', no matter the number of counts in the indictment, the volume of issues which may have arisen in a trial lasting several months or the complexities of the sometimes novel law, have to be made in writing on no more than 10 double-spaced A4 sheets of paper or 3000 words, and may be supplemented by a speech lasting no more than 45 minutes. The prosecution, as in other jurisdictions has the right to appeal against a sentence, which they consider to be too lenient, but at The Hague they also have the right of appeal against the Tribunal's decision to acquit. Even more surprisingly, the Appeal Chamber can find an appellant guilty of additional counts and can then proceed to add further sentences.

Perhaps the most alarming rule requires the defence to call evidence in mitigation of sentence during the trial and before the defendant has been convicted. If the prosecution challenges such evidence, it may go to weaken and taint the defence case. If, for example, evidence is called from a psychologist to show a degree of mental instability, it may go to show that the unlikely may very well have happened. The justification for such a rule - that it is administratively cheaper and more convenient to take all the evidence together - hardly holds water, since such evidence will have been a waste of time if the defendant is acquitted. Unfortunately, the impression is once again given that a defendant before the Tribunal is presumed to be guilty until proved to be innocent.

All such procedures push the concept of what is a fair trial beyond the limits usually encountered in the British courts. It may be that few of these matters will arise in the Milosevic trial, but if they do, the Tribunal should not be surprised if they cause questions of fairness to be raised.

\section{SO, CAN MILOSEVIC EXPECT A FAIR TRIAL?}

So far about 32 defendants out of 80 indicted before the Tribunal (with 50 who are currently in proceedings before 
it) have been tried on pleas of 'not guilty'. Only five have been acquitted, four on appeal. This is much lower than the acquittal rate before British criminal courts.

Although Milosevic has made it clear that he refuses to recognise the court, he has been cross examing witnesses. If his challenges are not to the substance of the witness's evidence and he offers no evidence on his own behalf, the trial will be one-sided and he is even less likely to succeed. The trial can continue without such participation but without it there may be no or little foundation for submissions to be made on his behalf on any number of counts against him. On the other hand, the Tribunal will lean over backwards to ensure that he is not procedurally prejudiced by not having a lawyer representing him in court. It would have been unlikely, for example, to allow counsel to go on for four hours with an argument, which is not relevant to the client's guilt or innocence. Furthermore, Milosevic now enjoys the three-fold advantage of being seen as a defendant on his own against the power of the international communities' lawyers, being able to receive the advice of lawyers outside the court if he so wishes and having what are called 'advisers to the court', appointed by the Tribunal, to draw to their attention any points of law which might conceivably help him and which they might either have missed or would seek to hear argument about.

Since international public opinion seems to be strongly against Milosevic, he may be fortunate in not having a jury to try him. It may even be his good fortune not to be being tried in Belgrade. We can assume that judges who are expected to exclude all prejudicial sentiments and to try the case upon a rational consideration of the evidence and the law, and who will moreover have to perform under the intense scrutiny of the world's lawyers and informed opinion, will be more likely to acquit than a jury.

It is impossible to know, of course, whether in due course Milosevic will be acquitted or convicted and of what alleged offences. It will depend entirely on the strength of the evidence against him: and particularly whether there is a sufficient evidential link between his actions and the undeniable horrors that were directly perpetrated by others upon so many people.

This much can be said at this early stage of the proceedings: that his appointed judges, two of whom have been nurtured on the English system of the common law, not only have substantial experience of war crimes cases at the Hague but can be expected to have a good appreciation of the criticisms that have been levelled against the Tribunal, its laws and its procedures. They will want to ensure that the justice done in their chamber is seen by the entire world to be fair.

Moreover, it is almost certain that an International Criminal Court will be set up in The Hague to try international crimes other than genocide and crimes against humanity in the former Yugoslavia and Rwanda. It will be modelled upon the Tribunal that will try Milosevic. That court will stand no chance of world acceptability if the judges, laws and procedures upon which it is to be based are seen to be operating unfairly in the highest profile international trial that the world has seen for half a century.

Of course we will not know if the trial has been fair until it is over. But I am confident that, despite everything, the Tribunal is as likely to provide a fair trial as any court in the world.

It is certain that Milosevic would not prefer to be tried with the al Qaida suspects at Guantanamo Bay - before a military tribunal whose proceedings are to be in secret, with no right of appeal and the possibility of a death sentence to follow.

Sir Ivan Lawrence QC 